\title{
Interaction of Arsenic with Zinc and Organics in a Rice (Oryza sativa L.)-Cultivated Field in India
}

\author{
D.K. Das ${ }^{1, *}$, T.K. Garai $^{1}$, S. Sarkar ${ }^{2}$, and Pintu Sur ${ }^{1}$ \\ ${ }^{1}$ Department of Agricultural Chemistry and Soil Science, ${ }^{2}$ Department of Agricultural \\ Meteorology and Physics, Bidhan Chandra Krishi Viswavidyalaya, Mohanpur 741 \\ 252, Nadia, West Bengal, India \\ E-mail: dkdas1231@sify.com; pintu_soil@yahoo.com
}

Received February 22, 2005; Revised May 9, 2005; Accepted May 24, 2005; Published August 18, 2005

A laboratory experiment on an Inceptisol with pH 7.6, organic carbon $6.8 \mathrm{~g} \mathrm{~kg}^{-1}$, and 0.5 $\mathrm{M} \mathrm{NaHCO}_{3}$ extractable arsenic $0.4 \mathrm{mg} \mathrm{kg}^{-1}$ was conducted to study the interaction effect of graded levels of arsenic $\left(0,5\right.$, and $\left.10 \mathrm{mg} \mathrm{kg}^{-1}\right)$ with zinc $\left(0,10\right.$, and $\left.20 \mathrm{mg} \mathrm{kg}^{-1}\right)$ and organics (0, 1, and $2 \%$ on soil weight basis) separately on the mobilization of arsenic in soils.

The results show that the amount of $0.5 \mathrm{M} \mathrm{NaHCO}_{3}$ extractable arsenic at pH 8.5 increased with the progress of submergence up to 35 days. However, the increase in arsenic concentration was correlated with decreasing application of graded levels of $\mathrm{Zn}$ as zinc sulfate. The intensity of reduction varied with varying levels of $\mathrm{Zn}$, being higher $\left(0.73-2.72 \mathrm{mg} \mathrm{kg}^{-1}\right)$ in the treatment where $\mathrm{Zn}$ was at $10 \mathrm{mg} \mathrm{kg}^{-1}$ and lower $(0.70-1.08 \mathrm{mg}$ $\mathrm{kg}^{-1}$ ) with $\mathrm{Zn}$ at $20 \mathrm{mg} \mathrm{kg}^{-1}$ application.

The amount of arsenic content in the soil significantly decreased with the application of varying levels of organics. However, such depressive effect was found more pronounced with well-decomposed farm yard manure than that of vermicompost. The results of field experiments showed that the grain yield between continuous flooding (4.84 $\mathrm{t} \mathrm{ha}^{-1}$ ) and intermittent flooding up to $\mathbf{4 0}$ days after transplanting then continuous flooding (4.83 $\mathrm{t} \mathrm{ha}^{-1}$ ) with the application of $\mathrm{ZnSO}_{4}$ at $25 \mathrm{~kg} \mathrm{ha}^{-1}$ did not vary. The lowest grain yield (3.65 $\mathrm{t} \mathrm{ha}^{-1}$ ) was recorded in the treatment where intermittent flooding was maintained throughout the growth period without the application of $\mathrm{Zn}$. The amount of arsenic content was, however, recorded much lower in the treatment where intermittent flooding throughout the growth period was maintained with $\mathrm{ZnSO}_{4}$.

KEYWORDS: arsenic, interaction, organics, rice soil, zinc

\section{INTRODUCTION}

In Asian countries, the highest number of people consuming and using arsenic-contaminated drinking water and groundwater for irrigation purposes suffer from arsenicosis, which has been reported by Chakravarty and Das[1]. Out of nineteen (19) districts in West Bengal, recently nine (9) districts are arsenic affected where cropping intensities are very high. For the agricultural crop production, 
particularly boro (summer) rice, during the lean period (i.e., March to May, the period for scarcity of water), a large amount of groundwater loaded with arsenic is used for irrigating agricultural crops.

Mandal[2] reported that 8-9 million people in West Bengal are affected by arsenic toxicities due to consuming such arsenic-contaminated groundwater for domestic use. The average arsenic contamination in the drinking water is about $0.20 \mathrm{mg} \mathrm{l}^{-1}$ with a maximum concentration of $3.7 \mathrm{mg} \mathrm{l}^{-1}$. Based on World Health Organization (WHO) specification $\left(0.05 \mathrm{mg} \mathrm{l}^{-1}\right)$, about $45 \%$ of the tested drinking water is toxic. Chakravarty and Das[1] also reported that due to the use of such water for irrigation purposes, arsenic concentration occurs in the soil and subsequently enters into different parts of crops (including the economic products) and ultimately enters into humans and animals, causing various anomalies and carcinogenesis.

Rice, a main cereal crop in South East Asian countries, is especially susceptible to arsenic toxicity compared to upland crop plants because of the increase in both the availability and toxicity of arsenic under the reducing condition of submerged soils. Arsenic pollution in soil may have toxic effects in vegetation and can adversely affect the animals that feed on that vegetation. Phytotoxicity studies have shown that $7 \mathrm{ppm}$ soluble arsenic causes injury to rice[3] and $9 \mathrm{ppm}$ to peas, beans, and barley[4]. It has also been reported that the toxicity of arsenic may be reduced by applying sulfates of zinc, iron, and aluminum to the soil[5]. Very limited research has so far been carried out about the interaction of arsenic with $\mathrm{Fe}, \mathrm{Zn}$, and organic matter in soils in relation to rice.

Keeping this in mind, the present study was undertaken to investigate the interaction of arsenic with $\mathrm{Zn}$ and organics in the soil cultivated with rice (Oryza sativa L.). The objective of our research was to optimize water use efficiency with a view to minimize arsenic buildup in soil vis-à-vis absorption by rice without the yield reduction.

\section{EXPERIMENTAL METHODS}

A laboratory experiment was conducted in an Aeric Endoaquepts (with pH 7.6, $0.5 \mathrm{M} \mathrm{NaHCO}_{3}$ extractable arsenic of $0.22 \mathrm{mg} \mathrm{kg}^{-1}$ ) to study the influence of $\mathrm{Zn}$ and organic matter on arsenic mobility in the soil. Arsenic doses were $0\left(\mathrm{As}_{0}\right), 5\left(\mathrm{As}_{1}\right)$, and $10\left(\mathrm{As}_{2}\right) \mathrm{mg} \mathrm{kg}{ }^{-1}$; $\mathrm{Zn}$ doses were $0\left(\mathrm{Zn}_{0}\right), 10\left(\mathrm{Zn}_{1}\right)$, and $20\left(\mathrm{Zn}_{2}\right) \mathrm{mg} \mathrm{kg}^{-1}$; and organic matter (O) well-decomposed farm yard manure (FYM) and vermicompost (V) each at $0\left(\mathrm{O}_{0}\right.$ and $\left.\mathrm{V}_{0}\right), 1\left(\mathrm{O}_{1}\right.$ and $\left.\mathrm{V}_{1}\right)$, and $2 \%\left(\mathrm{O}_{2}\right.$ and $\left.\mathrm{V}_{2}\right)$ on weight basis were applied to all possible treatment combinations replicated thrice in a completely randomized block design. The effect of $\mathrm{Zn}$ and organic matter with arsenic were studied separately.

A field experiment was conducted on an arsenic-contaminated Aeric Endoaquept soil of Gotera village in the district of Nadia, India with summer rice (cv. IET 4786) as a test crop having soil physicochemical properties of $\mathrm{pH}$ 7.6, $0.5 \mathrm{M} \mathrm{NaHCO}_{3}$ extractable arsenic $1.48 \mathrm{mg} \mathrm{kg}^{-1}$. The experimental plot $\left(30 \times 17.5 \mathrm{~m}^{2}\right)$ was divided into 12 main plots $\left(6 \times 4.5 \mathrm{~m}^{2}\right)$ with each main plot being further subdivided into 2 subplots $\left(3 \times 4.5 \mathrm{~m}^{2}\right)$ in a split-plot design with four replicates. Recommended levels of 100 , 50, and $50 \mathrm{~kg} \mathrm{ha}^{-1} \mathrm{~N}, \mathrm{P}_{2} \mathrm{O}_{5}$, and $\mathrm{K}_{2} \mathrm{O}$ were applied to each subplot, where half of the $\mathrm{N}$ and full $\mathrm{P}_{2} \mathrm{O}_{5}$ and $\mathrm{K}_{2} \mathrm{O}$ were applied as basal and one-fourth of the $\mathrm{N}$ was top dressed at active tillering and panicle initiation stage. Two to three 30-day-old seedlings were transplanted at a spacing of $15 \times 15 \mathrm{~cm}$. The source of irrigation water was shallow-tube well containing $0.26 \mathrm{mg} \mathrm{l}^{-1}$ arsenic. The main plot treatments received three levels of irrigation water namely (1) continuous ponding $\left(\mathrm{I}_{0}\right)$, (2) intermittent ponding $\left(\mathrm{I}_{1}\right)$, and (3) intermittent ponding up to 40 days of crop growth and then continuous ponding for the entire crop growth period $\left(\mathrm{I}_{2}\right)$. The subplot treatment was two levels of $\mathrm{Zn}\left(\mathrm{Zn}_{0}\right.$ and $\mathrm{Zn}_{1}$, at $\left.25 \mathrm{~kg} \mathrm{ha}^{-1} \mathrm{ZnSO}_{4}\right)$. Then rice was allowed to grow until the harvest. Soil and plant samples were collected periodically and also at harvest for the estimation of the arsenic content in both soils and plants. Arsenic was determined with the help of an atomic absorption spectrophotometer after extracting soils with $0.5 \mathrm{M} \mathrm{NaHCO}_{3}$ at $\mathrm{pH}$ 8.5[6] and plant samples were digested with ternary acid mixture of $\mathrm{HClO}_{4}: \mathrm{HNO}_{3}: \mathrm{H}_{2} \mathrm{SO}_{4}(10: 4: 1)$ [7]. 


\section{RESULTS AND DISCUSSION}

The results (Table 1) show that a slight increase in the amount of arsenic content was found in native soil due to submergence in an absolute control treatment $\left(\mathrm{As}_{0} \mathrm{Zn}_{0}\right)$. The amount of arsenic content in the soil significantly decreased with the application of $\mathrm{Zn}$; the highest recorded decrease (38.4\%) with $10 \mathrm{mg} \mathrm{kg}^{-1}$ Zn compared to $20 \mathrm{mg} \mathrm{kg}^{-1}$ (31.5\%) Zn application after 35 days of submergence. The results also show that the amount of arsenic content consistently increased with the progress of submergence due to application of arsenic. The rate of increase, however, was recorded lower and higher at the initial and later period of submergence, which might be due to varying intensity of reduction of arsenate to arsenite with the progress of submergence. Mukhopadhyay et al.[8] reported that after 14 days of submergence, soil had Eh values of $-115 \mathrm{mV}$ and, under these conditions, arsenate was reduced to arsenite. Arsenite, a more toxic form of arsenic, would be an important factor in the low Eh and $\mathrm{pH}$ levels of a flooded soil system.

TABLE 1

Effect of $\mathrm{Zn}$ and Arsenic Application on the Mobilization of Arsenic $\left(\mathrm{mg} \mathrm{kg}^{-1}\right)$ in a Submerged Soil

\begin{tabular}{|c|c|c|c|c|c|c|c|c|c|c|c|c|c|c|c|c|c|c|c|c|}
\hline \multirow[b]{2}{*}{ Treatmerts } & \multicolumn{20}{|c|}{ Doys after Stimengence } \\
\hline & 7 & & & & 14 & & & & 21 & & & & 28 & & & & 35 & & & \\
\hline $\begin{array}{l}\frac{\mathrm{Z}_{n}}{\mathrm{Zn}} \\
\mathrm{Zn} \\
\text { Mem }\end{array}$ & $\begin{array}{l}A s \\
0.23 \\
0.16 \\
0.19 \\
0.19\end{array}$ & $\begin{array}{l}\text { As } \\
235 \\
127 \\
122 \\
161\end{array}$ & $\begin{array}{l}\mathrm{AS} \\
2.48 \\
1.43 \\
1.53 \\
181\end{array}$ & $\begin{array}{c}\text { Mem } \\
168 \\
095 \\
098\end{array}$ & $\begin{array}{l}\text { As } \\
031 \\
020 \\
024 \\
025\end{array}$ & $\begin{array}{l}\text { As } \\
2.98 \\
1.33 \\
1.51 \\
1.94\end{array}$ & $\begin{array}{l}\text { As } \\
2.79 \\
1.48 \\
1.68 \\
198\end{array}$ & $\begin{array}{c}\text { Mem } \\
2.02 \\
101 \\
1.14\end{array}$ & $\begin{array}{l}A s \\
034 \\
025 \\
029 \\
020\end{array}$ & $\begin{array}{l}\text { As } \\
3.17 \\
1.00 \\
1.78 \\
2.18\end{array}$ & $\begin{array}{l}A E \\
387 \\
189 \\
207 \\
261\end{array}$ & $\begin{array}{c}\text { Mem } \\
2.46 \\
124 \\
138\end{array}$ & $\begin{array}{l}A S \\
038 \\
028 \\
032 \\
032\end{array}$ & $\begin{array}{l}A_{S} \\
3.42 \\
192 \\
2.11 \\
2.48\end{array}$ & $\begin{array}{l}A s \\
4.16 \\
2.21 \\
2.41 \\
2.92\end{array}$ & $\begin{array}{c}\text { Mfem } \\
2.65 \\
1.47 \\
1.61\end{array}$ & $\begin{array}{l}A_{E} \\
0.36 \\
0.30 \\
0.35 \\
0.33\end{array}$ & $\begin{array}{l}\text { As } \\
3.49 \\
2.22 \\
2.39 \\
2.71\end{array}$ & $\begin{array}{l}\mathrm{AS} \\
436 \\
2.48 \\
288 \\
3.24\end{array}$ & $\begin{array}{r}\text { Mem } \\
2.73 \\
1.68 \\
1.87\end{array}$ \\
\hline $\begin{array}{l}\text { CD }(y= \\
005)\end{array}$ & 0.14 & 021 & 024 & & 0.16 & 0.30 & 025 & & 027 & 032 & 028 & & 0.18 & 033 & 0.42 & & 0.19 & 0.41 & 039 & \\
\hline
\end{tabular}

With regard to interaction between $\mathrm{Zn}$ and arsenic, it was found that the amount of available arsenic content decreased; maximum amount with the $\mathrm{Zn}_{10} \mathrm{As}_{5}$ treatment combination, although the concentration of arsenic was minimum in all treatments with $\mathrm{Zn}$ and without the addition of arsenic. The results, therefore, confirmed that the $\mathrm{Zn}$ has pronounced effect in reducing the available arsenic concentration in a submerged soil[9].

Tables 2 and 3 show that the amount of arsenic content decreases with the increase of organic matter application, irrespective of sources. The magnitude of such decreases, however, varied with sources and levels of applied organic matter; greater decrease (18.30\%) with higher levels of vermicompost (2\% by weight of soil) application compared to corresponding levels of well-decomposed organic matter (14.01\%) after 50 days of submergence. The same trend was followed for the changes of arsenic concentration in the soil due to application of arsenic where the concentration of the same increased up to 25 days of submergence and thereafter its concentration decreased at 50 days of submergence.

Considering the interaction effect between vermicompost and arsenic, it was recorded that the amount of arsenic content decreases irrespective of treatments. The highest decrease was recorded in $\mathrm{As}_{0} \mathrm{~V}_{1}$ and $\mathrm{As}_{0} \mathrm{~V}_{2}$ treatment combinations where the arsenic was not applied. The decrease was maximum with $\mathrm{As}_{1} \mathrm{O}_{2}$ treatment combination where arsenic at $5 \mathrm{mg} \mathrm{kg}^{-1}$ was applied together with $2 \%$ vermicompost by weight of soil, which might be due to formation of insoluble arseno-organic complexes and its adsorption on to organic colloids[10]. 
TABLE 2

Effect of Well-Decomposed Organic Matter on the Mobilization of Arsenic $\left(\mathrm{mg} \mathrm{kg}^{-1}\right)$ in the Soil

\begin{tabular}{|c|c|c|c|c|c|c|c|c|c|c|c|c|}
\hline \multirow{3}{*}{ Treatments } & \multicolumn{12}{|c|}{ Arsenic Concentration $\left(\mathrm{mg} \mathrm{kg}^{-1}\right)$ at Different Days of Incubation } \\
\hline & \multicolumn{4}{|c|}{10 Days } & \multicolumn{4}{|c|}{25 Days } & \multicolumn{4}{|c|}{50 Days } \\
\hline & $A s_{0}$ & $A s_{1}$ & $A s_{2}$ & Mean & $A s_{0}$ & $A s_{1}$ & $\mathrm{As}_{2}$ & Mean & $A s_{0}$ & $A s_{1}$ & $\mathrm{As}_{2}$ & Mean \\
\hline $\mathrm{O}_{0}$ & 2.05 & 2.58 & 3.73 & 2.78 & 2.89 & 3.32 & 4.14 & 3.45 & 2.63 & 3.13 & 3.89 & 3.10 \\
\hline $\mathrm{O}_{1}$ & 2.09 & 2.50 & 3.74 & 2.77 & 2.73 & 3.15 & 3.87 & 3.25 & 2.43 & 3.87 & 3.78 & 3.03 \\
\hline $\mathrm{O}_{2}$ & 2.15 & 2.43 & 3.66 & 2.74 & 2.67 & 3.23 & 3.78 & 3.22 & 2.12 & 2.63 & 3.53 & 2.76 \\
\hline Mean & 2.09 & 2.50 & 3.71 & & 2.76 & 3.23 & 3.90 & & 2.39 & 2.88 & 3.73 & \\
\hline$C D(p=0.05)$ & 0.10 & 0.18 & 0.15 & & 0.12 & 0.14 & 0.15 & & 0.17 & 0.21 & 0.19 & \\
\hline
\end{tabular}

TABLE 3

Effect of Vermicompost on the Mobilization of Arsenic $\left(\mathrm{mg} \mathrm{kg}^{-1}\right)$ in the Soil Studied

\begin{tabular}{|c|c|c|c|c|c|c|c|c|c|c|c|c|}
\hline \multirow{3}{*}{ Treatments } & \multicolumn{12}{|c|}{ Arsenic Concentration $\left(\mathrm{mg} \mathrm{kg}^{-1}\right)$ at Different Days of Incubation } \\
\hline & \multicolumn{4}{|c|}{10 Days } & \multicolumn{4}{|c|}{25 Days } & \multicolumn{4}{|c|}{50 Days } \\
\hline & $\mathrm{As}_{0}$ & $A \mathbf{s}_{1}$ & $A s_{2}$ & Mean & $\mathrm{As}_{0}$ & $A s_{1}$ & $\mathrm{As}_{2}$ & Mean & $\mathrm{As}_{0}$ & $A s_{1}$ & $\mathrm{As}_{2}$ & Mean \\
\hline $\mathrm{V}_{0}$ & 2.13 & 2.48 & 3.89 & 2.83 & 2.76 & 3.51 & 4.18 & 3.48 & 2.59 & 3.23 & 3.71 & 3.17 \\
\hline$V_{1}$ & 2.12 & 2.67 & 3.77 & 2.85 & 2.54 & 3.42 & 3.86 & 3.27 & 2.24 & 2.88 & 3.43 & 2.85 \\
\hline $\mathrm{V}_{2}$ & 2.16 & 2.42 & 3.64 & 2.74 & 2.69 & 3.59 & 3.71 & 3.33 & 2.01 & 2.65 & 3.13 & 2.59 \\
\hline Mean & 2.13 & 2.52 & 3.76 & & 2.66 & 3.50 & 3.92 & & 2.28 & 2.91 & 3.42 & \\
\hline$C D(p=0.05)$ & 0.11 & 0.20 & 0.18 & & 0.24 & 0.17 & 0.21 & & 0.25 & 0.29 & 0.17 & \\
\hline
\end{tabular}

Table 4 shows that the amount of arsenic buildup in the soil up to 75 days of submergence (3.98 $\mathrm{mg}$ $\mathrm{kg}^{-1}$ ) significantly increased in the treatment where $\mathrm{Zn}$ was not applied. With regard to irrigation water management practices, it was recorded that the amount of arsenic buildup in the soil was found to be the highest (3.64 mg kg$\left.{ }^{-1}\right)$ in $\mathrm{I}_{0}$ treatment, followed by $\mathrm{I}_{1}\left(3.58 \mathrm{mg} \mathrm{kg}^{-1}\right)$ and $\mathrm{I}_{2}\left(2.75 \mathrm{mg} \mathrm{kg}^{-1}\right)$ irrespective of $\mathrm{Zn}$ applications. Such buildup of arsenic in the soil, however, has been found to be further counteracted by the application of $\mathrm{ZnSO}_{4}$ at $25 \mathrm{~kg} \mathrm{ha}^{-1}$, as seen from the interaction effects between $\mathrm{Zn}$ and methods of applying irrigation water.

Considering the interaction effect between $\mathrm{Zn}$ and methods of water irrigation, the lowest amount of arsenic in the soil $\left(1.98 \mathrm{mg} \mathrm{kg}^{-1}\right)$ was recorded on $\mathrm{Zn}_{1} \mathrm{I}_{1}$ treatment $\left(\mathrm{ZnSO}_{4}\right.$ at $\left.25 \mathrm{~kg} \mathrm{ha}^{-1}\right)$ with intermittent ponding up to $75 \mathrm{~cm}$ of crop growth. The arsenic toxicity may be reduced by applying sulfates of $\mathrm{Zn}, \mathrm{Fe}$, and $\mathrm{Al}$ to the soil[5,9]. Such decrease in its concentration might be due to the suppressing effect of $\mathrm{Zn}$ that results in precipitation/fixation of arsenic as Zn-arsenate, which makes it unavailable to plants[11].

$$
\text { Arsenate }+\mathrm{ZnSO}_{4} \rightarrow \mathrm{Zn} \text {-arsenate }
$$

(Insoluble and unavailable to the plant)

The results further show that the accumulation of arsenic in different parts of rice plants varied with treatments in the following order:

$$
\text { Root }>\text { Stem }>\text { Leaf }>\text { Grain. }
$$


TABLE 4

Effect of Arsenic-Contaminated Irrigation Water and Zn Fertilizers on the Mobility of Arsenic in Soil from a Field Cultivated with Rice (O. sativa L.) in India

\begin{tabular}{|c|c|c|c|c|c|c|c|c|c|c|c|c|c|c|c|c|c|c|}
\hline \multirow[t]{2}{*}{ Tre atments } & \multicolumn{3}{|c|}{$\begin{array}{l}\text { Arsenic Concertration } \\
\text { (mgkg ) in Soil after } 75 \\
\text { Dyss of Growth }\end{array}$} & \multicolumn{11}{|c|}{ Arsenic Contert in Fice (mg kg) } & \multicolumn{4}{|c|}{ Grain Yield (tha) } \\
\hline & $Z_{n}$ & $\mathrm{Zn}$ & Me m & $z_{n}$ & $z_{n}$ & Mem & $z_{n}$ & $z_{n}$ & Mean & $Z n$ & $\mathrm{Zn}_{\mathrm{n}}$ & Meam & $Z_{n}$ & $Z_{n}$ & Mean & $\mathrm{Zn}$ & $Z_{n}$ & Mean \\
\hline$I_{1}$ & 4.48 & 281 & 364 & 8.93 & 887 & 890 & 6.97 & 6.87 & 6.92 & 698 & 686 & 6.92 & 1.03 & 0.94 & 098 & 4.01 & 484 & 4.42 \\
\hline$I_{1}$ & 395 & 321 & 358 & 8.31 & 801 & 8.16 & 6.19 & 5.98 & 6.08 & 624 & 6.10 & 6.17 & 0.98 & 0.88 & 093 & 3.80 & 483 & 431 \\
\hline $\mathrm{I}_{2}$ & 353 & 198 & 2.75 & 7.71 & 7.15 & 7.43 & 6.35 & 5.14 & 5.24 & 5.78 & 5.49 & 5.63 & 0.96 & 0.81 & 0.88 & 3.65 & 4.19 & 392 \\
\hline $\begin{array}{l}\text { Mean } \\
\text { CD }(p=0.05)\end{array}$ & 398 & 266 & & 8.31 & 801 & & 6.17 & 5.99 & & 633 & 6.15 & & 0.99 & 0.87 & & & & \\
\hline I & & 0.66 & & & 029 & & & 0.37 & & & 035 & & & 029 & & & 029 & \\
\hline $\mathrm{Zn}$ & & 0.82 & & & 0.19 & & & 0.28 & & & 031 & & & 023 & & & 0.42 & \\
\hline $\mathrm{I} \times \mathrm{Zn}$ & & 1.42 & & & 037 & & & 0.48 & & & 0.53 & & & 039 & & & 0.73 & \\
\hline
\end{tabular}

The highest accumulation of arsenic in roots as compared to stems, leaves, and grains might be due to its less mobility within the plant, which supports the results reported by Liu et al.[12 ] who showed the distribution of arsenic in plants was in the following order: Root $>$ Stem $>$ Leaf $>$ Edible parts. Depression of rice growth seems to depend on the amount of arsenite in the soil and arsines damage the roots of rice, resulting inhibition of nutrient uptake[13]. Accumulation of arsenic in rice roots, stems, leaves, and grains was found to have decreased significantly with the application of either $\mathrm{Zn}$ or management of irrigation water or both; the lowest significantly in root $\left(7.15 \mathrm{mg} \mathrm{kg}^{-1}\right)$, stem $(5.14 \mathrm{mg}$ $\mathrm{kg}^{-1}$ ), leaf (5.49 $\left.\mathrm{mg} \mathrm{kg}^{-1}\right)$, and grain $\left(0.81 \mathrm{mg} \mathrm{kg}^{-1}\right.$ ) with the application of $\mathrm{Zn}$ under intermittent ponding throughout the growth period of rice compared to other water management practices.

The highest amount of water was used in the treatment $\mathrm{I}_{0}\left(160 \mathrm{~cm} \mathrm{ha}^{-1}\right)$ followed by $\mathrm{I}_{1}\left(124 \mathrm{~cm} \mathrm{ha}^{-1}\right)$ and $\mathrm{I}_{2}\left(102 \mathrm{~cm} \mathrm{ha}^{-1}\right)$ for the growth of rice without affecting the yield of rice and without increasing the concentration of arsenic in both the soil and its uptake by rice plant. The grain yield of rice was recorded the highest in $\mathrm{Zn}_{1} \mathrm{I}_{0}$ treatment combination $\left(4.98 \mathrm{t} \mathrm{ha}^{-1}\right)$, which was closely followed by $4.83 \mathrm{t} \mathrm{ha}^{-1}$ in $\mathrm{Zn}_{1} \mathrm{I}_{1}$ treatment. Although, a slight decrease in the yield was recorded in $\mathrm{Zn}_{1} \mathrm{I}_{2}$ treatment $\left(4.19 \mathrm{t} \mathrm{ha}^{-1}\right)$, but the concentration of arsenic in different parts of the rice plant and its buildup in the soil was significantly lower.

Considering the arsenic pollution problems, $\mathrm{Zn}_{1} \mathrm{I}_{1}$ treatment combination was superior in relation to marginal yield increase as well as reducing arsenic concentration in both soil and plants[14].

\section{REFERENCES}

1. Chakravarty, A.K. and Das, D.K. (1997) Arsenic pollution and its environmental significance. J. Interacademicia 1, 262-276.

2. Mandal, R.K. (1998) Status of Arsenic Problem in Two Blocks Out of Sixty-Eight Groundwater Arsenic Affected Districts of West Bengal, India [Ph.D.thesis]. School of Environmental Studies, Jadavpur University, and Kolkata, India.

3. Epps, E.A. and Sturgis, M.B. (1939) Arsenic compounds toxic to rice. Soil Sci. Soc. Am. Proc. 4, $215-218$.

4. Bishop, R.F. and Chisholm, D. (1962) Arsenic accumulation in Annapois valley orchard soils. Can. J. Soil Sci. 42, 77-80.

5. $\quad$ Brady, N.C. (1974) The Nature and Properties of Soils. $8^{\text {th }}$ ed. Macmillan, New York.

6. Johnston, L.R. and Barnard, W.M. (1979) Comparative effectiveness of fourteen solutions for extracting arsenic from four Western New York soils. Soil Sci. Soc. Am. J. 43, 304-308.

7. Jackson, M.L. (1973) In Soil Chemical Analysis. Prentice-Hall of India, New Delhi.

8. Mukhopadhyay, R., Fisher, T.R, and Smith, G.E. (1967) Submergence and liming effects on soil. 1. Changes in pH, Eh and manganese uptake by rice plants. Soil Sci. 104, 107-112.

9. Garai, T.K., Das, D.K., and Sarkar, S. (2000) Effect of Iron and Zinc Application on the Availability of Native and Applied Arsenic Simulating Low Land Rice Condition. Paper presented at the International Conference on Managing Natural Resources for Sustainable Agricultural Production in the 21 ${ }^{\text {st }}$ Century, New Delhi, February 14-18.

10. Mukhopadhyay, D. and Sanyal, S.K. (2002) Studies on arsenic transport across and down in some soils of West Bengal. J. Indian Soc. Soil Sci. 50, 456-463. 
11. Craw, D. and Chappell, R. (2000) Metal redistribution in historic mine wastes, Coromondal Peninsula, New Zealand. J. Geol. Geophys. 43,187-189.

12. Liu, G.L., Cheng, F.X., Gao, S.D., and Li, M.Q. (1985) Effect of arsenic in soil on plants. Zhonggno Nongye Kexue (Beijing) 4, 9-16.

13. Takamatsu, T., Aoki, H., and Yoshida, T. (1983) Arsenic speciation in pot soil cropped with rice plant, fluctuations of arsenate, arsenite, monomethylearsonate and dimethyle arsinate contents. Kokuritsu Kogai Kenkyusho Kenkyu Hokoku 47, 153-163.

14. Ghosh, K., Das, Indranil, Das, D.K., and Sanyal, S.K. (2003) Crop Uptake, Retention and Release of Arsenic in Some Arsenic Contaminated Soils of Bengal Delta Basin. In Abstract: National Seminar on $68^{\text {th }}$ Annual Convention of Indian Society of Soil Science, Kanpur, November 4-8. pp. 34-35.

This article should be referenced as follows:

Das, D.K., Garai, T.K., Sarkar, S., and Sur, P. (2005) Interaction of arsenic with zinc and organics in a rice (Oryza sativa L.)cultivated field in India. TheScientificWorldJOURNAL 5, 646-651.

\section{Handling Editor:}

A.R. Mermut, Associate Editor for Soil Systems — a domain of TheScientificWorldJOURNAL.

\section{BIOSKETCHES}

D.K. Das, Professor in the Department of Agricultural Chemistry and Soil Science, has 25 years of experience in teaching on the undergraduate and postgraduate level, and research relating to soil chemistry, soil fertility, and plant nutrition. Prof. Das has published about 100 original research papers in national and international journals of repute and has also published six books from Kalyani Publishers, India. http://myprofile.cos.com/dkdas

T.K. Garai was a Senior Research Fellow of this project work funded by the Indian Council of Agricultural Research (ICAR), New Delhi, India

S. Sarkar, Professor in the Department of Agricultural Meteorology and Physics, has approximately 20 years of experience in teaching and research with particular reference to water management in agricultural production systems. Prof. Sarkar has published a good number of research papers in journals of national and international repute.

Pintu Sur is a Research Fellow in the Department of Agricultural Chemistry and Soil Science, Bidhan Chandra Krishi Viswavidyalaya, West Bengal, India. Sri Sur has published three research papers in journals of national and international repute. 


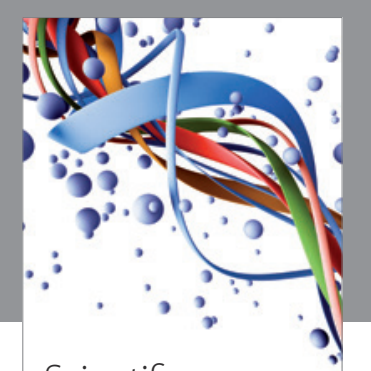

Scientifica
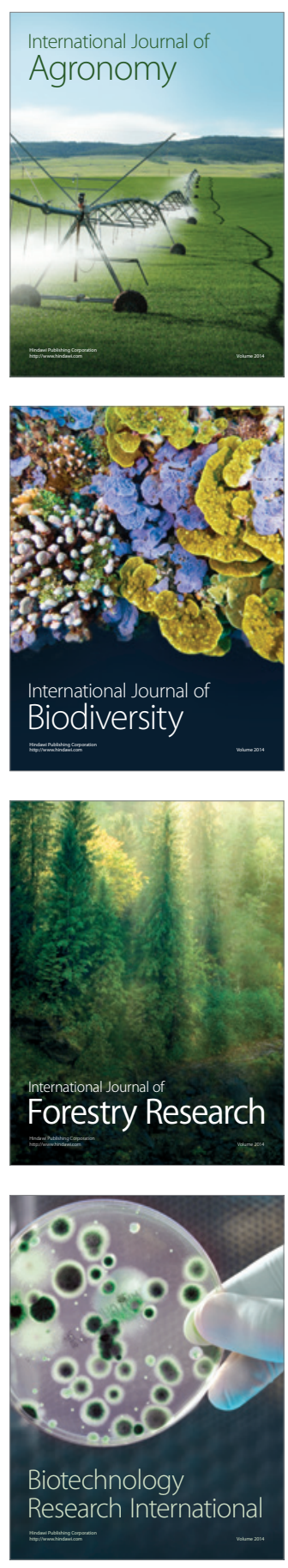
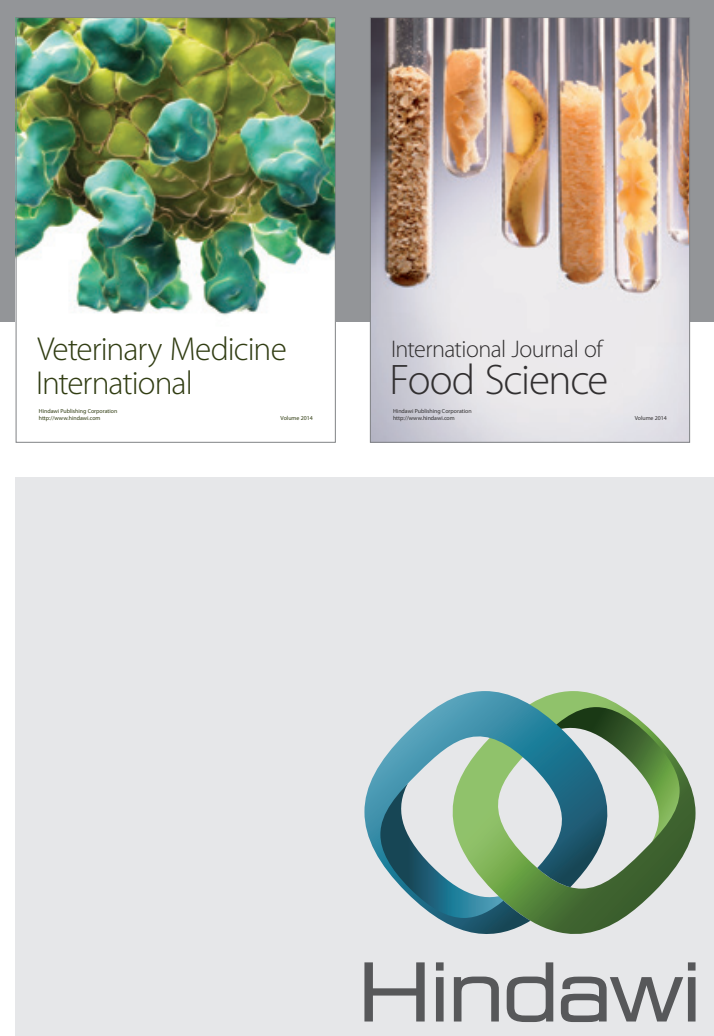

Submit your manuscripts at

http://www.hindawi.com
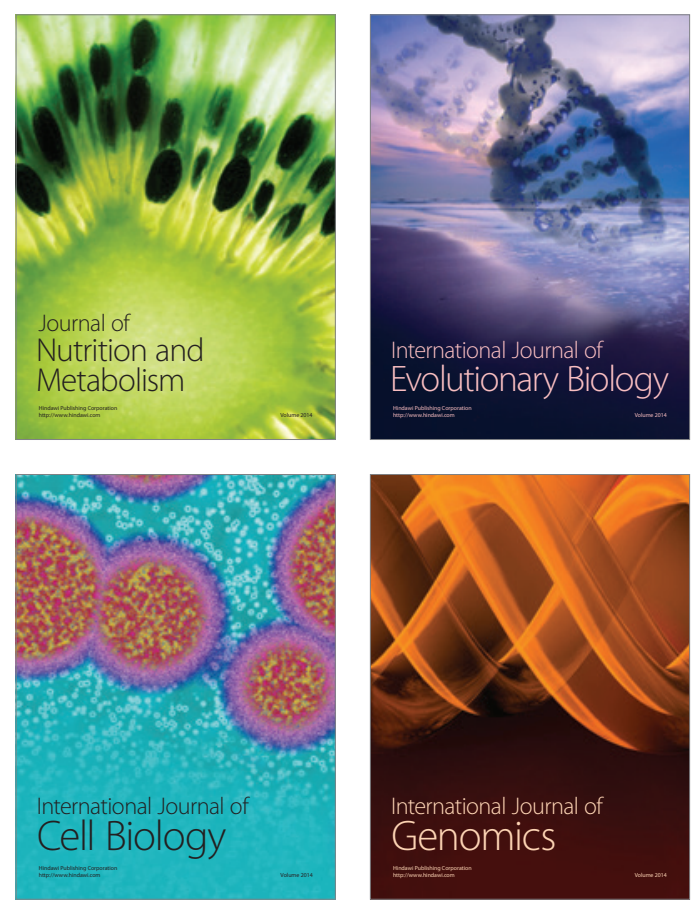
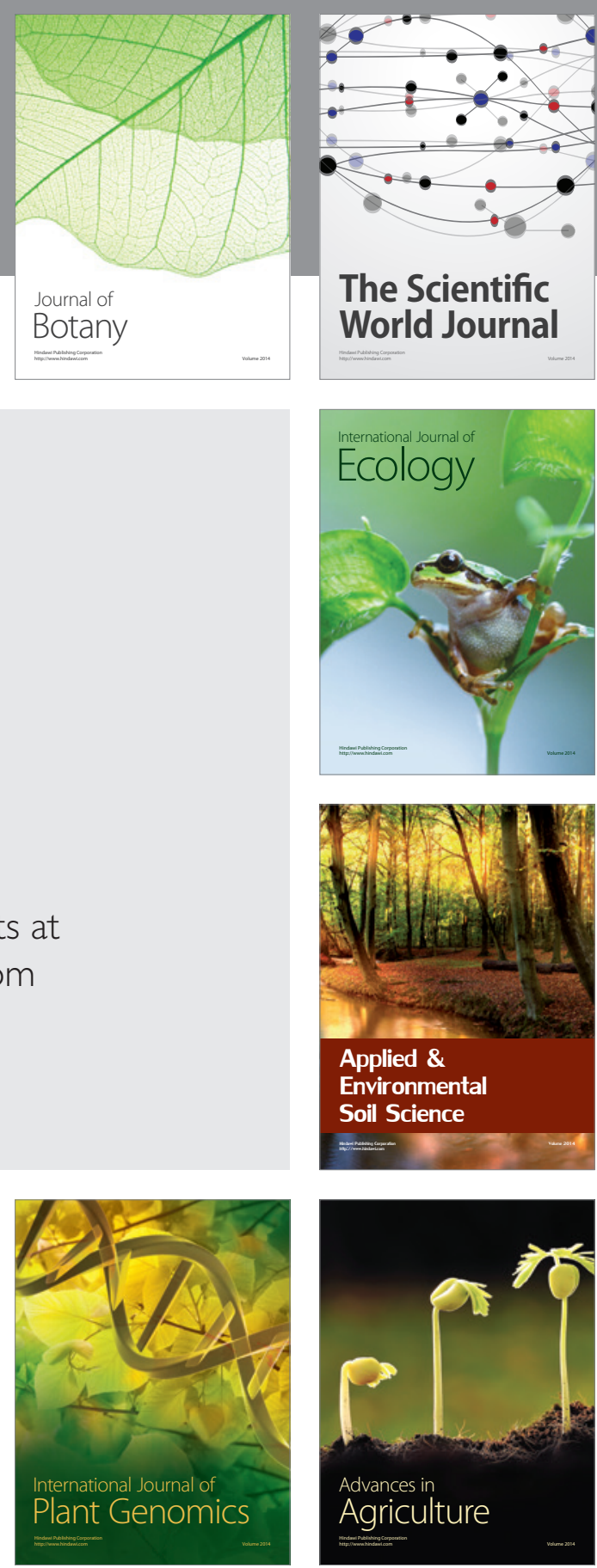

The Scientific World Journal
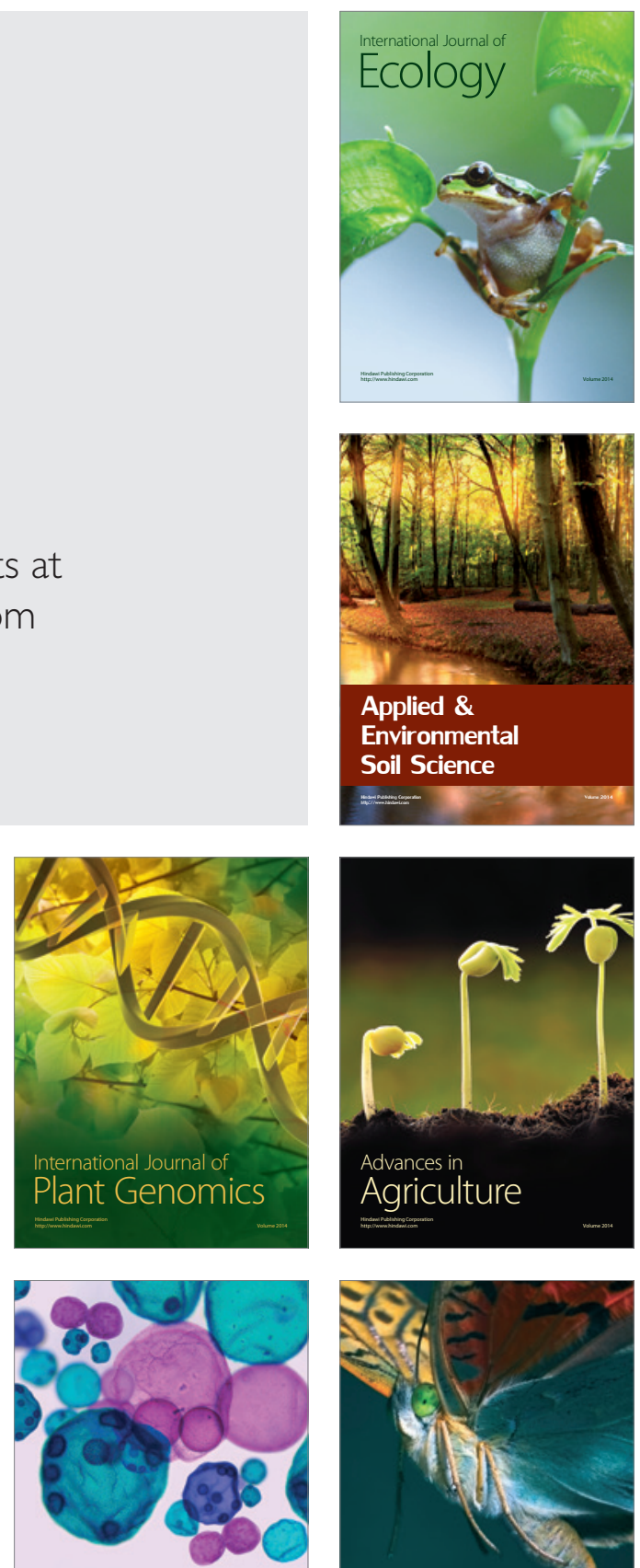

International Journal of Microbiology

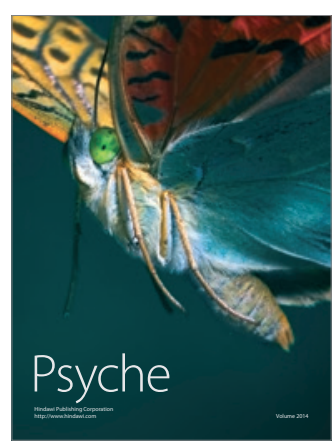

